\title{
PELATIHAN PEMBUATAN KERAJINAN BERBAHAN PLASTIK BEKAS
}

\section{TRAINING MAKING CRAFTS BASED PLASTIC WASTE}

\author{
${ }^{1)}$ Yudha Febrianta, ${ }^{2)}$ Ahmad Fauzan \\ ${ }^{1)}$ Program Studi PGSD, ${ }^{2}$ Program Studi PBSI, Fakultas Keguruan dan Ilmu Pendidikan \\ Universitas Muhammadiyah Purwokerto \\ Jl.Raya Dukuh Waluh PO BOX 202 Purwokerto 53182 \\ Email: yudha.febrianta@yahoo.co.id
}

\begin{abstract}
ABSTRAK
Tujuan dari kegiatan ini adalah memberikan keterampilan membuat kerajinan dengan bahan baku limbah rumah tangga, mendistribusikan atau memasarkan hasil kerajinan. Metode yang digunakan adalah pelatihan, praktek langsung, pendampingan, pembinaan dan kemitraan dengan Yayasan Yatim Piatu di Baturaden Purwokerto. Capaian pelatihan adalah anak-anak memiliki keterampilan dalam mengolah sampah plastik dan botol bekas sehingga memiliki nilai yang lebih ekonomis. Selain itu anak-anak memiliki kreativitas yang tinggi dalam menciptakan produk yang lebih variasi.
\end{abstract}

Kata kunci : pelatihan, pembuatan, kerajinan, berbahan bekas

\section{ABSTRACT}

The purpose of this activity is to provide the skills to make crafts with household waste materials, distribute or market their crafts. The method used is the training, direct practice, mentoring, coaching and partnership with the Foundation for Orphans in Baturaden Purwokerto. The achievement of the training is the kids have skills in processing plastic waste and bottles that have a value that is more economical. In addition children have high creativity in creating products that are more variations.

Keywords: training, manufacturing, handicrafts, made the former

Submited : 30 Nopember 2016 Revision : 2 Desember 2016 Accepted : 21 Januari 2017

\section{PENDAHULUAN}

Kawasan Wisata Baturaden yang berada di Kabupaten Basnyumas merupakan salah satu daerah tujuan wisata yang cukup potensial. Dari sebelas obyek wisata yang ada di Kabupaten Banyumas sebanyak lima obyek wisata berada di Kawasan Wisata Baturaden. Kawasan Wisata Baturaden menjadi kawasan wisata unggulan Kabupaten Banyumas yang banyak dikunjungi oleh masyarakat Kabupaten Banyumas sendiri maupun masyarakat di kabupaten-kabupaten sekitarnya. Baturaden telah dikenal sebagai kawasan wisata dengan berbagai obyek wisata yang ada dan fasilitas pendukungnya yang cukup lengkap. Selain wisatawan regional, wisatawan mancanegara juga banyak yang berkunjung ke Baturaden, sehingga skala pelayanan selain regional juga internasional (Kusmiati, 2011)

Kunjungan ke tempat wisata Baturaden sempat menurun dikarenakan kabar Gunung Slamet mulai aktif lagi, kemudian dengan berita seperti itu maka wisatawan berkurang. Masyarakat daerah wisata Baruraden membangun sebuah Yayasan Yatim Piatu yang berada di desa Karangsoka tersebut sudah menampung anak yatim piatu sebanyak 35 anak mayoritas berdomisili di Karangsoka. Yayasan Yatim Piatu itu masih sangat minim kegiatan pada pengembangan kemampuan yang menunjang ekonomi dari anak yatim piatu tersebut.. kegiatan masih difokuskan pada kegiatan yang 
menyangkut pendidikan saja. Kegiatan yang non kependidikan masih sangat minim.

Permasalahan yang dihadapi oleh mitra yaitu pemberdayaan kegiatan yang dilakukan di Yayasan Yatim Piatu belum optimal, anak-anak yang sudah tidak mempunyai orang tua harapannya bisa melakukan kegiatan yang bermanfaat dan dapat memberikan inkam atau pemasukan untuk kehidupannya sehari-hari bersama keluarga. Yayasan merupakan wadah untuk menampung sekelompok orang yang dikelola untuk memperbaiki taraf kehidupan dari kelompok dalam wadah tersebut. Yayasan Yatim Piatu Karangsoka yang berada di wilayah kecamatan Purwokerto berada di daerah kawasan Wisata Baturaden. Melihat letak Yayasan Yatim Piatu yang strategis di daerah wisata, maka Yayasan memiliki keinginan untuk membekali anak-anak dengan keterampilan membuat kerajinan dengan bahan baku limbah rumah tangga yang dihasilkan dari rumah-rumah yang berada di sekitar wisata.

Melihat permasalahan di atas maka perlu diadakan pelatihan untuk membuat kerajinan dari limbah rumah tangga yang bisa diolah sehingga memperoleh nilai jual yang tinggi. Melihat kondisi demikian pelatihan ini akan membekali anak-anak yang berada di Yayasan Yatim Piatu Karangsoka untuk memiliki keterampilan membuat kerajinan sekaligus memberikan pelatihan dalam mendistribusikan atau memasarkan hasil kerajinan tersebut, karena daerah wisata terdapat banyak limbah dari bahan plastik, maka pelatihan ini akan memberikan keterampilan dalam mengolah bahan bekas plastik sehingga bisa dimanfaatkan lagi dan memiliki nilai jual yang tinggi. Kerajinan yang akan dibuat dari bahan plastik bekas yaitu hiasan pintu, hiasan jendela, asbak, pot gantung, pot bunga, dan asbak.
Pelatihan yang akan dilaksanakan bertujuan untuk memberikan keterampilan serta kreativitas anak. Kreativitas memang sangat diperlukan dalam kehidupan seharihari. kemampuan seseorang untuk melahirkan sesuatu yang baru, baik berupa gagasan maupun karya nyata, yang relative berbeda dengan apa yang telah ada sebelumnya. Rhodes dalam Munandar (1999) mendefinisikan kreativitas sebagai berikut:" Kreativitas dapat dirumuskan dalam istilah pribadi (person), proses, dan produk. Kreativitas juga dapat ditinjau dari kondisi pribadi dan lingkungan yang mendorong (press). Rhodes kemudian menyebut keempat jenis devinisi kreativitas ini sebagai four $P$ 's of creativity: person, process, press, product. Keempat $P$ ini saling berkaitan:pribadikreatif yang melibatkan diri dalam proses kreatif dengan dukungan dan dorongan (press) dari lingkungan, menghasilkan produk kreatif

\section{METODE}

Untuk mengatasi permasalahan
sampah plastik yang berada di wilayah Baturaden, maka Yayasan Yatim Piatu akan diberikan pelatihan untuk mengolah sampah plastik menjadi bahan konsumtif yang memiliki nilai jual dan kualitas baik serta ekonomis. Pengolahan bahan bekas ini akan menjadi usaha dari Yayasan Yatim Piatu Karangsoka yang berada di wilayah Baturaden. Anak yatim piatu yang berada di Yayasan Yatim Piatu ini berasal dari keluarga yang kurang mampu. Pelaksanaan pengabdian ini dengan menggunakan metode pelathan terlebih dahulu, pelatihan dilakukan dengan bersama-sama. Pelatihan dipandu oleh beberapa mentor. Setelah pelatihan selesai kemudian praktik secara langsung dalam pembuatan kerajinan dari bahan bekas tersebut. Setelah semua anak membuat kerajinan dengan didampingi oleh mentor maka dalam pengemasan juga akan didampingi. Kerajinan yang 
sudah jadi nantinya akan diberi warna dengan cara mengecat kerajinan tersebut. Setelah dilakukan pengecatan kemudian dilakukan pengemasan. Tentunya dengan memberikan Label untuk produk kerajinan yang dibuat oleh anak-anak yatim piatu yang berada di Yayasan Yatim Piatu Karangsoka.

Pengemasan dan pelabelan telah dilakukan, kemudian produk itu dipasarkan di daerah wisata Baturaden dengan cara menitipkan pada took souvenir yang berada di daerah wisata tersebut. Harapannya dengan memasarkan produk yang telah dibuat oleh anak-anak Yatim Piatu, maka akan menjadikan wisata Baturaden semakin banyak dikunjungi oleh wisatawan baik dari domestik maupun mancanegara. Selain itu produk akan banyak dikenal oleh orang lain sehingga bisa juga dilakukan pemesanan untuk produk tersebut, sehingga produk itu bisa dikenal oleh banyak orang. Harapannya produk yang dibuat bisa digunakan untuk souvenir serta hiasan dirumah mampu untuk digunakan sendiri. Selain itu produk itu bisa memberikan inkam tambahan untuk keluarga, secara luas untuk semua masyarakat sehingga bisa membuat Usaha Kecil Menengah, kerajinan itu bisa menjadi ikon di kawasan Baturaden Purwokerto.

\section{HASIL DAN PEMBAHASAN}

Hasil kegiatan ini adalah:

1. Anak memiliki keterampilan dalam mengolah sampah plastik terutama botol bekas.

2. Anak memiliki kreatifitas dalam membentuk model kerajinan yang lebih variatif.
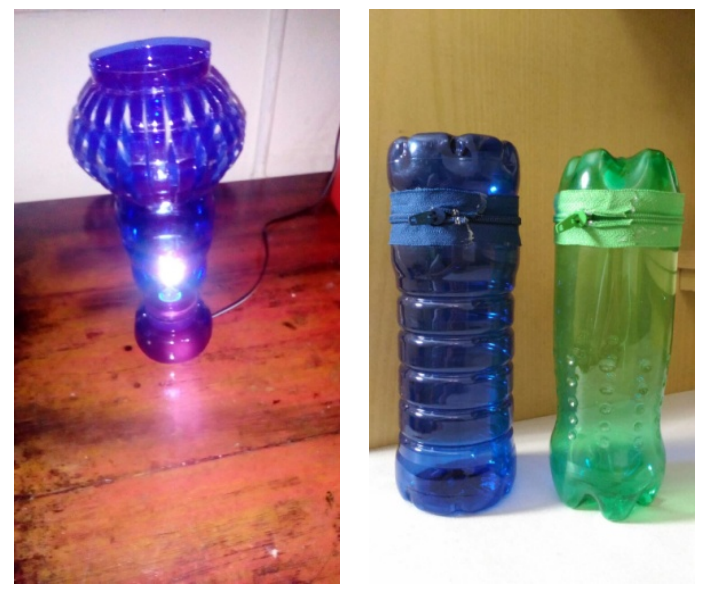

Hasil pelatihan anak-anak memiliki keterampilan dalam mengolah sampah plastik dan botol bekas sehingga memiliki nilai yang lebih ekonomis. Selain itu anak-anak memiliki kreativitas yang tinggi dalam menciptakan produk yang lebih variasi.

Dari beberapa kali pelatihan dan pendampingan, mulai dari pengenalan alatalat yang digunakan untuk membuat kerajinan membuat anak-anak mengerti atau paham kegunaan alat tersebut. Kemudian melatihkan dengan membuat kerajinan yang sederhana terlebih dahulu hingga membuat kerajinan yang membutuhkan konsentrasi tinggi.

Kreativitas yang muncul mampu membuat anak-anak keluar ide hal ini sesuai dengan Kamus Besar Bahasa Indonesia (2005), kreativitas adalah kemampuan untuk mencipta, perihal berkreasi dan kekreatifan. Anak-anak mampu berkreatifitas setelah dilakukan pelatihan atau setelah diarahkan hal tersebut sesuai dengan pendapat Munandar (1985), kreativitas adalah kemampuan untuk membuat kombinasi baru, berdasarkan data, informasi atau unsurunsur yang ada. Dari pengarahan yang dilakukan maka timbul kreativitas anak. 
Bila tidak ada hambatan yang mengganggu perkembangan kreativitas, cukup aman untuk mengata kan semakin cerdas anak semakin dapat ia menjadi kreatif. Sebab, kreativitas tidak dapat berfungsi dalam ketidaktahuan. Ia menggunakan pengeta huan yang diterima sebelumnya, dan ini bergantung pada kemampuan intelektual seseorang. Maka dari itu, kreativitas belajar sangat penting sekali untuk didorong dan ditumbuh kembangkan pada diri anak.

$$
\text { Menurut Andang }
$$

Kreativitas dapat menjadi "kekuatan" (power) yang dapat menggerakkan manusia dari "tidak tahu" menjadi "tahu", dari "tidak bisa" menjadi "bisa", dari "bodoh" menjadi "cerdas", dari "pasif" menjadi "aktif" dan sebagainya, tinggal manusianya, apakah kreativitas yang ada pada diri setiap orang itu dikembangkan, atau justru malah dimatikan. Anak-anak mampu membuat kerajinan yang berbahan plastik dan botol bekas hingga mampu membuat barang yang tidak terpakai itu memiliki daya nilai tinggi. Anak-anak timbul kreatifitas untuk membuat kerajianan dengan berbagai fariasi sehingga timbul kreatifitas yang tinggi.

Setelah dilatihkan membuat kerajinan anak-anak juga dilatihkan untuk mengemas produk yang telah mereka buat sehingga lebih menarik dan lebih memiliki nilai jual.

\section{SIMPULAN}

Anak-anak memiliki keterampilan dalam mengolah sampah plastik dan botol bekas sehingga memiliki nilai yang lebih ekonomis. Selain itu anak-anak memiliki kreativitas yang tinggi dalam menciptakan produk yang lebih fariasi.

Dengan diberikan pelatihan untuk memasarkan produk kerajinan maka anakanak akan mampu mempromosikan sendiri hasil kerajinan. Untuk memperbaiki produk kerajiann perlu melihat kebutuhan konsumen dan mampu membuat hal yang baru dengan media plastik dan botol bekas.

\section{DAFTAR PUSTAKA}

Alwi, H, dkk. (2005). Kamus Besar Bahasa Indonesia. Jakarta : Departemen Pendidikan Nasional Balai Pustaka.

Andang, I. (2006). Education Games; Menjadi Cerdas dan Ceria dengan Permainan Edukatif. Yogyakarta : Pilar Media.

Kurniasti, N., (2011). Tahap Perkembangan Obyek Wisata Kabupaten Banyumas Provinsi Jawa Tengah. Skripsi. FMIPA, Departemen Geografi, Universitas Indonesia.

Munandar, S.C.U (1985). Mengembangkan Bakat dan Kreativitas Anak Sekolah. Jakarta : Grasindo 